\title{
A BTT-Based Colorimetric Dual Sensor for Hg(II) and Selected Anions with Molecular Logic Operations
}

\author{
Veikko Uahengo, ${ }^{1,2}$ Ping Cai, ${ }^{2}$ and Likius S. Daniel ${ }^{1}$ \\ ${ }^{1}$ Department of Chemistry and Biochemistry, University of Namibia, 340 Mandume Ndemufayo Avenue, Windhoek 9000, Namibia \\ ${ }^{2}$ College of Chemistry and Molecular Sciences, Wuhan University, Wuhan, Hubei 430072, China \\ Correspondence should be addressed to Veikko Uahengo; vuahengo@gmail.com and Ping Cai; caiping@whu.edu.cn
}

Received 27 February 2016; Accepted 16 May 2016

Academic Editor: Ipsita Banerjee

Copyright (c) 2016 Veikko Uahengo et al. This is an open access article distributed under the Creative Commons Attribution License, which permits unrestricted use, distribution, and reproduction in any medium, provided the original work is properly cited.

\begin{abstract}
A benzotrithiophenes (BTT) based colorimetric sensor (2) was synthesized via a simple one-step reaction process, and its recognition properties towards several biologically important anions and cations were investigated by naked eye observation and spectroscopic methods of UV-vis and ${ }^{1} \mathrm{H}$ NMR analysis in DMSO. The molar addition of anions such as $\mathrm{F}^{-}, \mathrm{AcO}^{-}$, and $\mathrm{H}_{2} \mathrm{PO}_{4}^{-}$ induced a marked red shift of the charge transfer band $(\Delta \lambda=94 \mathrm{~nm}$, from $440 \mathrm{~nm}$ to $534 \mathrm{~nm})$ concomitant with a clearly visible "naked eye" detectable colorimetric activities (from orange to pink). However, the molar addition of $\mathrm{H}_{2} \mathrm{PO}_{4}{ }^{-}$did not induce significant spectral changes, compared to $\mathrm{F}^{-}$and $\mathrm{AcO}^{-}$. Furthermore, the molar addition of $\mathrm{Hg}^{2+}$ to 2 resulted in hypochromic shift at $440 \mathrm{~nm}$ and the eventual disappearance of a low energy band at $534 \mathrm{~nm}$, concomitant with the colorimetric activities (from orange to yellow). Moreover, both spectral and color changes induced by the addition of anions $\left(\mathrm{F}^{-}\right.$and $\left.\mathrm{AcO}^{-}\right)$were all reversible by the molar addition of metal cations of $3 \mathrm{~d}^{5-10}$. The reversibility properties triggered the logic operation studies, and, subsequently, the complementary IMP/INH logic functions based on color and spectral switching (ON/OFF) were confirmed. Conclusively, 2 can thus be utilized as a colorimetric molecular switch modulated by $\mathrm{AcO}^{-} / \mathrm{M}^{\mathrm{II}}$.
\end{abstract}

\section{Introduction}

Thiophene-based $\pi$-conjugated polymers and their derivatives have been attracting attention in organic electronic devices such as organic light emitting diodes (OLED), organic field effect transistors (OFET), organic photovoltaics (OPV), and electrochromics [1-10]. These functionalities are due to the disk-shaped planar conformation with rigid $\pi$-electron framework, which facilitate strong intermolecular interactions that are suitable for developing organic semiconductor materials. Benzotrithiophenes (BTT) are very unique due to their rare structure of $C_{3 h}$ symmetry with three identical thiophene groups resulting in a possible 3-dimensional starshaped structure. In fact, the star-shaped conformation has attracted much attention in recent times, especially in the field of organic semiconductors, due to its planarity, delocalized $\pi$-electron system, and highly organized 2-dimensional network, and it reportedly possesses high thermal stability [11-23].
However, despite their excellent fluorescent and polymerization properties, thiophene-based compounds have rarely been used in the development of chemosensors [24-31]. In theory, thiophene-based compounds can be very ideal for excellent sensor in designing, based on their structural engineering or/and manipulation, especially their disc-shape planar structure, presenting an ideal platform for smooth electronic communications. For instance, BTT with its $\pi$ electron framework is potentially likely to make an excellent chemosensor, especially when it is coupled with a powerful electron withdrawing group (EWG) such as the nitro group $\left(-\mathrm{NO}_{2}\right)$, fittingly resulting in a moiety with strong electronic coupling, from the receptor to the reporting unit. Hydrazonebased sensors for acetate and fluoride ions have been widely reported in literature, with the $-\mathrm{NH}$ protons acidity enhanced by the presence of powerful electron withdrawing groups, like $\mathrm{NO}_{2}$ and $\mathrm{CF}_{3}$ [32-37]. By using the principles of coupling a BTT, a strong electron donating group (EDG) itself, to another strong EWG with relatively low LUMO level such 


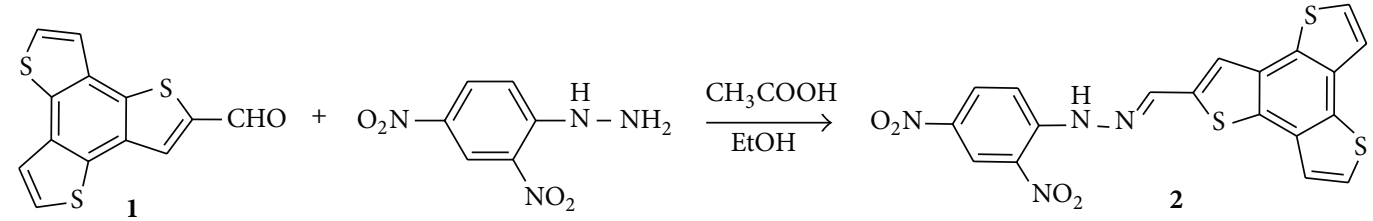

SCHEme 1: Synthetic route and the structure of 2.

as dinitrophenylhydrazine, is highly likely to produce a chemosensor with remarkable dynamic electronic communication. Moreover, the presence of soft (donor) atoms such as sulphur in the ring raises the prospect of dual sensing, for both cations and anions, which stems from the presence of both the anion receptors $(-\mathrm{NH})$ and the cationphilic (e.g., $\mathrm{Hg}^{2+}$ and $\mathrm{Zn}^{2+}$ ) thiophene group in the structure. In literature, it has been well documented that dual sensing systems are highly likely to display molecular logic operation properties.

In recent years, developments in supramolecular chemistry fields have shown that chemosensors can act as useful tools in information processing and computation at molecular level. In these systems, the chemically coded information is normally converted into optical changes as the output through electronic communications, generally between the receptor and the reporter units of the structure. Even though literature has reported a number of different molecular logic gates such as AND, OR, INIHIBIT, NOR, IMPLICATION, XOR, YES, NOT, NAND, and XNOR [29], combinatorial logic gates having complementary IMP/INH logic functions remain rare and elusive. The reported systems are generally devised by the modulation of either the emission properties or colorimetric changes and restored by different combinations of specific ionic species [38-44].

As a tributary of supramolecular chemistry, chemosensors are designed for a specific function based on complementary topological geometries and chemical properties of the target species. The significance of sensing of biologically important anions such as acetate, fluoride, and dihydrogen phosphate [29, 32-37] has been reported and highlighted in literature, and the same can be said for cations such as mercury, copper, and zinc [45-49]. However, ideal sensors with satisfactory performances, especially with combinatorial logic functions, still remain to be desired. Here we report on a two-way sensor based on a BTT-dinitrophenylhydrazone receptor (2) in Scheme 1, a dual colorimetric sensor selective to both cations $\left(\mathrm{Hg}^{2+}\right)$ and anions $\left(\mathrm{AcO}^{-}, \mathrm{F}^{-}\right.$, and partially $\left.\mathrm{H}_{2} \mathrm{PO}_{4}{ }^{-}\right)$. In addition, the sensor has displayed a reversible colorimetric system based on two inputs $\mathrm{F}^{-} / \mathrm{Zn}^{2+}$ complementary IMPLICATION/INHIBITION (IMP/INH) logic functions.

\section{Experimental}

2.1. Instruments. ${ }^{1} \mathrm{H} \mathrm{NMR}$ spectra were acquired on a Varian Mercury VX-300 MHz spectrometer. UV-vis spectra were recorded using a Tu-1901 UV-vis spectrophotometer $(1 \mathrm{~cm}$ quartz cell) at $25^{\circ} \mathrm{C}$. C, $\mathrm{H}$, and $\mathrm{N}$ elemental analyses were acquired on a Perkin-Elmer 240C analytical instrument.

2.2. Materials. Commercially available chemicals were used without further purification and were all of analytical grades. All tetrabutylammonium $\left(\mathrm{TBA}^{+}\right)$salts $\left(\mathrm{F}^{-}, \mathrm{Cl}^{-}, \mathrm{Br}^{-}, \mathrm{I}^{-}\right.$, $\mathrm{AcO}^{-}$, and $\left.\mathrm{H}_{2} \mathrm{PO}_{4}{ }^{-}\right)$, hydrated metal nitrate salts $\left(\mathrm{Hg}^{2+}\right.$, $\mathrm{Zn}^{2+}, \mathrm{Cu}^{2+}$, etc.), 1,3,5-trichlorobenzene, and all other chemicals were purchased from Sigma-Aldrich. All UV-vis titrations were performed in $1.0 \times 10^{-5} \mathrm{M}$ solution of 2 in DMSO except the Job plot $\left(1.0 \times 10^{-4} \mathrm{M}\right)$ or unless mentioned otherwise.

2.3. Synthesis and Characterization of 2. The sensor (2), (E)1-(benzo[1,2-b:3,4- $\left.\mathrm{b}^{\prime}: 5,6-\mathrm{b}^{\prime \prime}\right]$ trithiophen-2-ylmethylene)-2(2,4-dinitrophenyl) hydrazone, was synthesized as follows. Compound $1[15,50](0.0176 \mathrm{~g}, 0.26 \mathrm{mmol})$ and 2,4-dinitrophenylhydrazine $(0.053 \mathrm{~g}, 0.26 \mathrm{mmol})$ were dissolved in ethanol and $5 \mathrm{~mL}$ of $\mathrm{H}_{2} \mathrm{PO}_{4}$ was added. The solution mixture was refluxed while stirred magnetically for $8 \mathrm{~h}$ and a yellow precipitate formed. After cooling to room temperature, the yellow precipitate was washed repeatedly with small quantity of hot and then cold ethanol to yield a pure yellow solid (2). Yield was $85 \%$. ${ }^{1} \mathrm{HNMR}(300 \mathrm{MHz}$, DMSO-d) $\delta 11.60$ (s, $\left.\mathrm{H}_{\mathrm{NH}}\right), 8.86\left(\mathrm{~s}, 1 \mathrm{H}_{\mathrm{ben}}\right), 8.39\left(\mathrm{~s}, 1 \mathrm{H}_{\mathrm{ben}}\right), 8.36\left(\mathrm{~s}, 1 \mathrm{H}_{\mathrm{CH}}\right), 7.98$ (d, $\left.1 \mathrm{H}_{\text {ben }}\right), 7.61\left(\mathrm{~d}, 2 \mathrm{H}_{\text {thio }}\right), 7.41\left(\mathrm{~d}, 2 \mathrm{H}_{\text {thio }}\right), 7.39\left(\mathrm{~s}, 1 \mathrm{H}_{\text {thio }}\right)$. Elemental Analysis for $\mathrm{C}_{19} \mathrm{H}_{10} \mathrm{~N}_{4} \mathrm{O}_{4} \mathrm{~S}_{3}$ : Calculated C, $50.21 \%$, $\mathrm{H}, 2.22 \%, \mathrm{~N}, 14.08 \%$. Found C, 52.41\%, H, 2.41\%, N, 13.63\%.

\section{Results and Discussion}

3.1. UV-Vis Titration of $\mathbf{2}$ with Anions. The sensor (2) is characterized by two absorption bands in the visible region in DMSO, the high and low energy bands at $440 \mathrm{~nm}$ and $534 \mathrm{~nm}$, respectively, ascribed to the existence of charge transfer (CT) of the electron withdrawing 2,4-dinitrophenylhydrazone moiety and the electron donating BTT unit, respectively. The molar addition of anions $\left(\mathrm{AcO}^{-}\right.$and $\left.\mathrm{F}^{-}\right)$to 2 resulted in the intensity decrease of the band at $440 \mathrm{~nm}$, while intensity increase was experienced at $534 \mathrm{~nm}$ as shown in Figures 1(a) and 1(b). In addition to the spectral changes, the color of 2 changed from orange to purple (inset). An isosbestic point at $469 \mathrm{~nm}$ was indicating the existence of two distinctive species at equilibrium during the titration process. It is well known that the interaction of anions $\left(\mathrm{AcO}^{-}, \mathrm{F}^{-}\right.$, and $\mathrm{H}_{2} \mathrm{PO}_{4}{ }^{-}$) with hydrazone moiety is through hydrogen bonding with the $\mathrm{NH}$ proton in the sensor, the action ascribed to geometrical complementarity, and the chemical properties of the species 


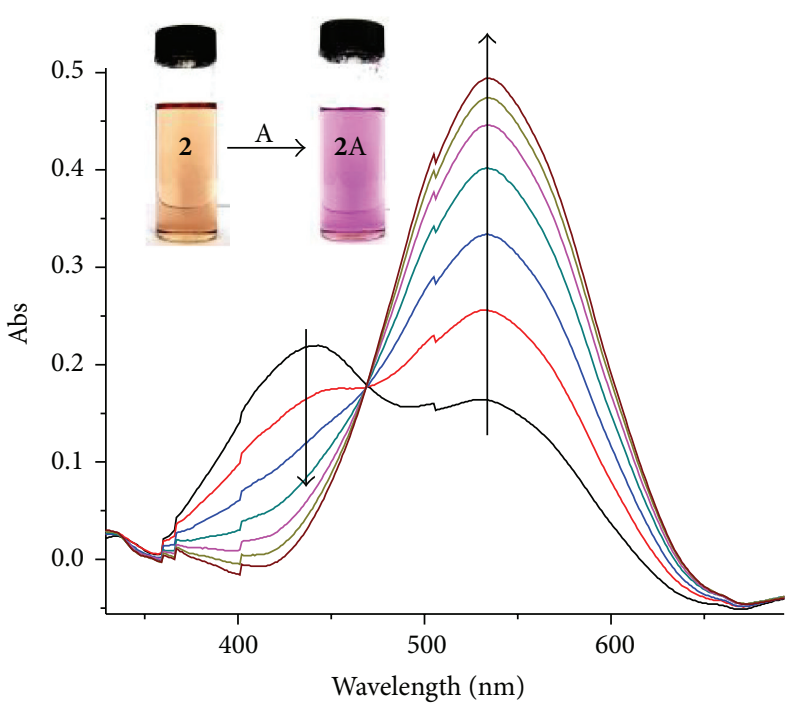

(a)

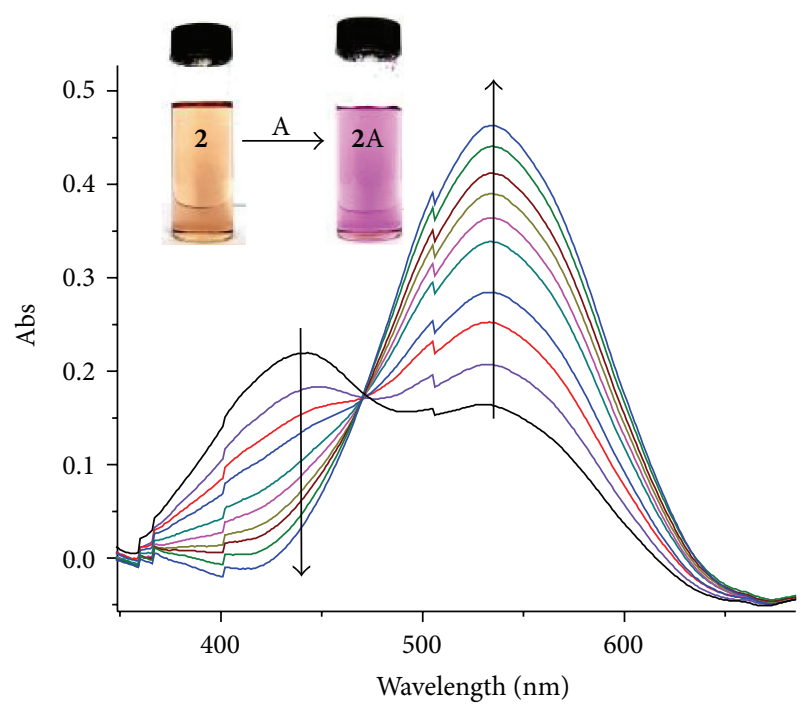

(b)

FIGURE 1: Changes in UV-vis absorption spectra of $2\left(1 \times 10^{-5} \mathrm{M}\right)$ upon the addition of 1 equiv. (a) $\mathrm{AcO}^{-}$and (b) $\mathrm{F}^{-}$, all in $\mathrm{DMSO}$ at $25^{\circ} \mathrm{C}$.

[32-37]. The addition of other anions $\left(\mathrm{Cl}^{-}, \mathrm{Br}^{-}, \mathrm{I}^{-}\right.$, and $\mathrm{H}_{2} \mathrm{PO}_{4}^{-}$) did not induce much significant or noticeable changes (Figure 2(c)). The glimpse on the interaction modes is suggested by the titration curves as shown in Figures 2(a) and 2(b). However, Job's plot displays a more complex binding mode (Figure 3).

3.2. UV-Vis Titrations of $\mathbf{2}$ with Cations. Interestingly, the addition of molar equivalents of $\mathrm{Hg}^{2+}$ to 2 resulted in the color changes from yellow to light yellow (almost colorless), which was concomitant with the disappearance of the spectra band at $534 \mathrm{~nm}$, while the increase in intensity was observed at $440 \mathrm{~nm}$ (Figure 4). The interaction is suspected to be of coordination nature involving two immediate cationphilic neighboring atoms (sulphur and nitrogen) and the mercury ion. The complementary size of $\mathrm{Hg}^{2+}$ is suspected to have played a major role in the selection preference. Conclusively, the coordination of $\mathrm{Hg}^{2+}$ to 2 interferes with the intermolecular charge transfer (ICT) between the electron rich $-\mathrm{NH}$ and the electron deficient $-\mathrm{NO}_{2}$ at $534 \mathrm{~nm}$, thereby disrupting charge transfer activities across the structural sphere, resulting in the disappearance of the peak at $534 \mathrm{~nm}$. Other cations such as $\mathrm{Cu}^{2+}$ and $\mathrm{Zn}^{2+}$ showed similar effects; however, none of them were able to vanquish the band $(534 \mathrm{~nm})$ completely, even when huge quantities were used. However, it appears that the reversibility properties (logic operations) which are modulated by inputs (cations and anions) are stronger than the coordination interactions to some extent, as discussed in the next section.

3.3. Reversibility and Logic Operations Studies. More details on interactions were obtained from the reversibility studies, which led to the conclusion that the reversible colorimetric activities of $\mathbf{2}$ upon the addition of anions and cations resemble two inputs with complementary "IMP/INH" logic functions. The addition of anions to $\mathbf{2}$ which resulted in spectral and naked eye colorimetric changes was reversed to their initial state, both spectra and color, when molar amount of cations $\left(\mathrm{Zn}^{2+}\right)$ was added (Figure 5(a)). The reversible yellow-orange-yellow-orange cycles were repeated several times ( 4 times) by alternating addition of 2 equiv. $\mathrm{F}^{-}$ and about 1.2 equiv. of $\mathrm{Zn}^{2+}$ with consistent and continuous cycles shown in Figure 5(b). The total amount of equiv. added during the four cycles was almost $1(2): 17 \mathrm{~F}^{-}: 7 \mathrm{Zn}^{2+}$, which has little effect on the absorption intensities of $\mathbf{2}$, even though the fourth cycle saw the molar amounts slightly increased, compared to the first three. Similar results to $\mathrm{Zn}^{2+}$ were obtained upon molar additions of $\mathrm{Cu}^{2+}$ in more or less equivalent ratios.

The logic operations of 2 are based on the reversibility and reproducibility of colorimetric-spectral switch upon mixing right combinations of $\mathrm{F}^{-}$and $\mathrm{Zn}^{2+}$. The addition of $\mathrm{F}^{-}$to 2 induces spectral and color changes (output ${ }_{534} \mathrm{~nm}$ ), while a further addition of $\mathrm{Zn}^{2+}$ to this solution reverses or reproduces the changes (output ${ }_{440 \mathrm{~nm}}$ ), both color and spectra, to restore the original position (2). This can be viewed as two different systems; first the output at $534 \mathrm{~nm}$ is controlled by two inputs, input-F and input- $\mathrm{Zn}$, the system resembling a molecular INH logic gate, represented by the truth table (Figure 6(a)). On the other hand, the output at $440 \mathrm{~nm}$ is controlled by the same inputs but different order represents IMP logic gate. According to the Boolean logic systems, the two systems resemble a two-input complementary IMP/INH logic functions (Figure 6(b)). In the 21st century, these systems of reversible-reproducible functions are of great interest in molecular level information processing. While molecular logic devices are already in use in some fields, applications in computational operations remain to be desired.

The interpretation of the logic operation functions is highlighted based on reversibility studies (Figure 7(a)). 

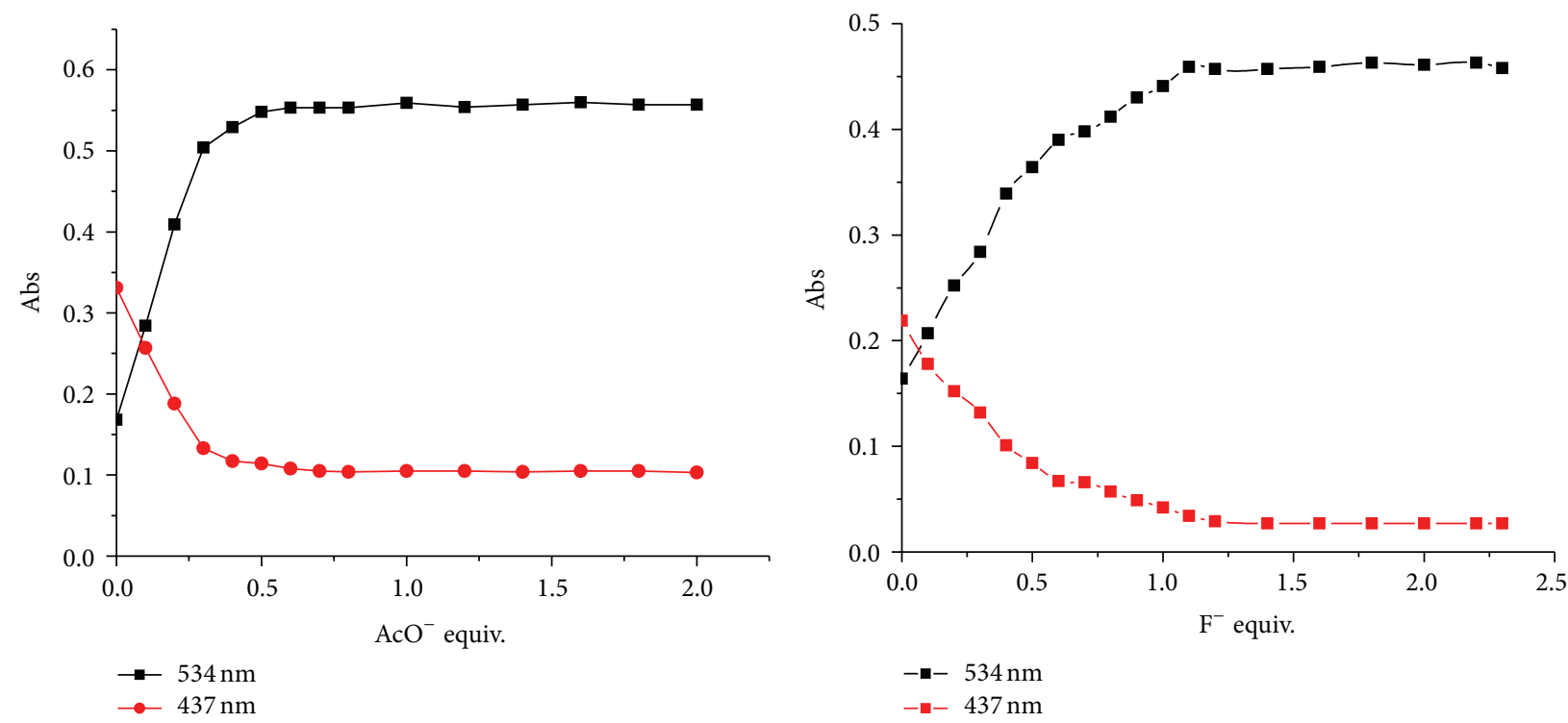

(a)

(b)

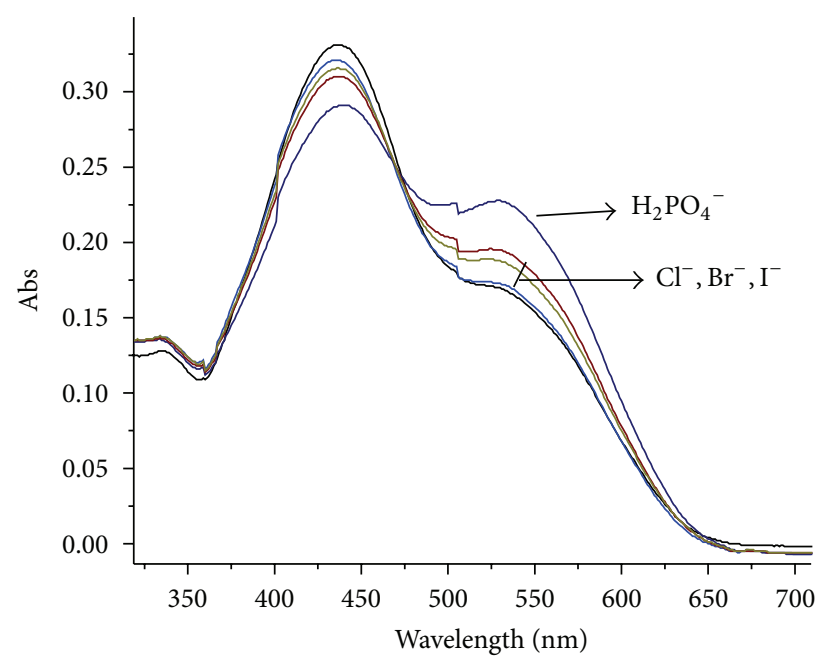

(c)

Figure 2: Titration profile on the band at $440 \mathrm{~nm}$ and $534 \mathrm{~nm}$ in (a) $\mathrm{AcO}^{-}$, (b) $\mathrm{F}^{-}$, and (c) $\mathrm{UV}$-vis absorption spectra of $\mathrm{Cl}^{-}, \mathrm{Br}^{-}, \mathrm{I}^{-}$, and $\mathrm{H}_{2} \mathrm{PO}_{4}{ }^{-}$, respectively, all in DMSO at $25^{\circ} \mathrm{C}$.

The addition of appropriate combinations of $\mathrm{F}^{-}$and $\mathrm{Zn}^{2+}$ as inputs yields the outputs which are equivalent with complimentary IMP/INH logic functions $[29,44]$. The process is triggered through the molar addition of input-1 $\left(\mathrm{F}^{-}, \mathrm{AcO}^{-}\right)$ at $534 \mathrm{~nm}$ and reversed by the molar addition of input-2 $\left(3 \mathrm{~d}^{5-10}\right)$. The spectral red shift which changes to $534 \mathrm{~nm}$ upon the addition of input-1 is complementary to INH logic gate, while the reversed activities at $440 \mathrm{~nm}$ are complementary to IMP logic gate. More additions of inputs have no significant effect on the absorption of the solution, as evidenced by the number of cycles performed (Figure 5(b)). Moreover, colorimetric activities are concentration-dependent, where colors intensify upon the increase of concentration (Figure 7(b)).
3.4. In Depth Study on the Interaction of 2 with $\mathrm{Hg}^{2+}$ and $\mathrm{Zn}^{2+}$. The addition of cations $\left(\mathrm{Hg}^{\mathrm{II}}\right.$ and $\left.\mathrm{Zn}^{\mathrm{II}}\right)$ to 2 displayed different spectral behaviors compared to anions, which prompted further investigation in order to have a clear understanding on the interaction behaviors of the species involved. The addition of $\mathrm{Hg}^{\mathrm{II}}$ or $\mathrm{Zn}^{\mathrm{II}}$ to 2 resulted in the "naked eye" detectable color change, from orange to yellowish (almost colorless), concomitant with spectral changes, at $440 \mathrm{~nm}$ and $534 \mathrm{~nm}$ (Figure 4). Individually, the addition of 0.3 equiv. $\mathrm{Hg}^{\mathrm{II}}$ to 2 resulted in the complete disappearance of the absorption band at $534 \mathrm{~nm}$, initially assigned to the benzotrithiophene moiety and the intensity increase of the band at $440 \mathrm{~nm}$. Contrastingly, similar behaviors were observed upon the addition of $\mathrm{Zn}^{\mathrm{II}}$ to 2 ; however, the absorption band at $534 \mathrm{~nm}$ 


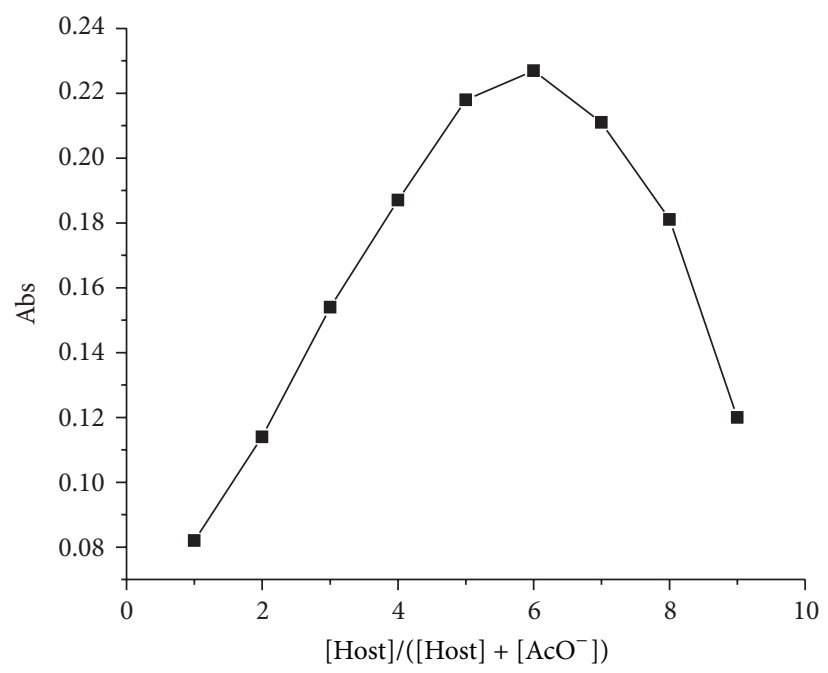

(a)

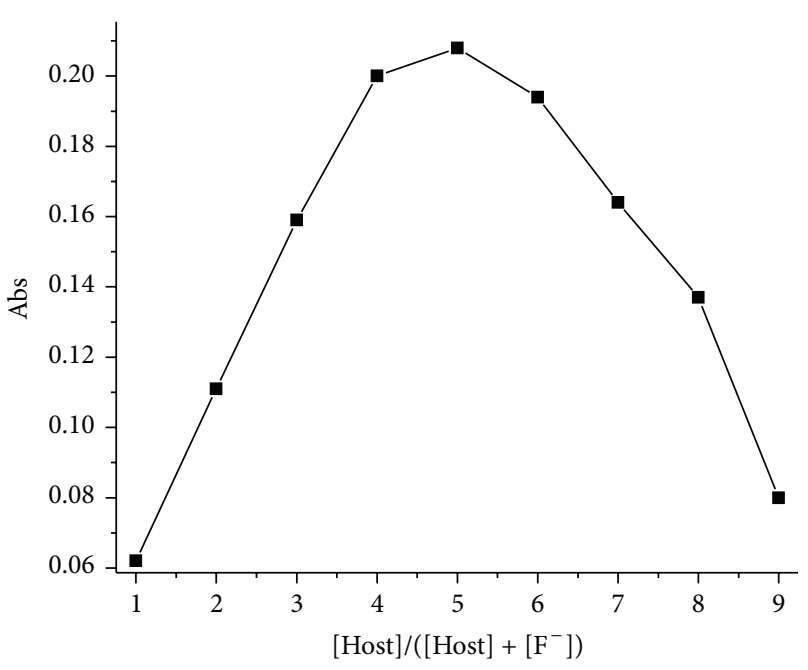

(b)

Figure 3: Job's plot for (a) $\mathrm{AcO}^{-}$and (b) $\mathrm{F}^{-}$, both in DMSO at $1 \times 10^{-4} \mathrm{M}$.

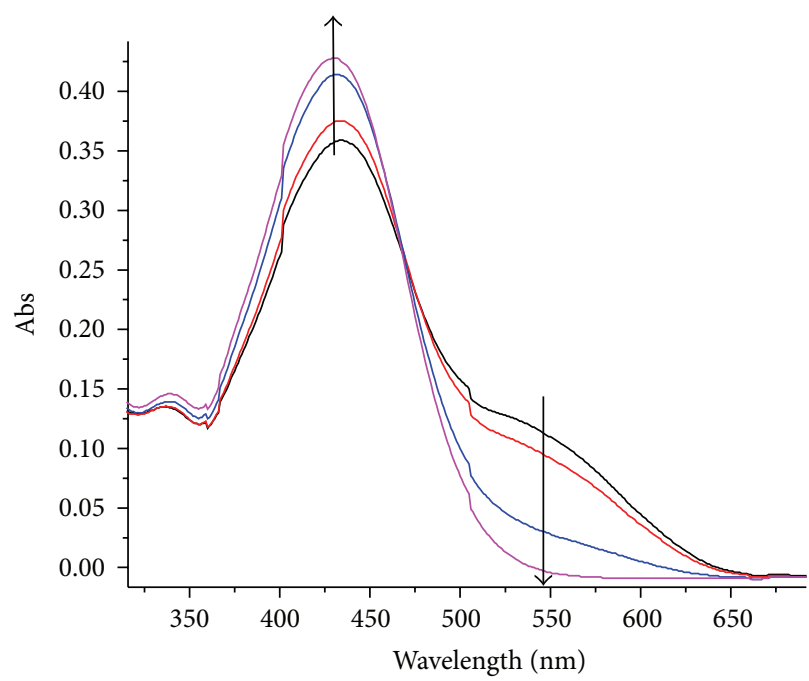

(a)

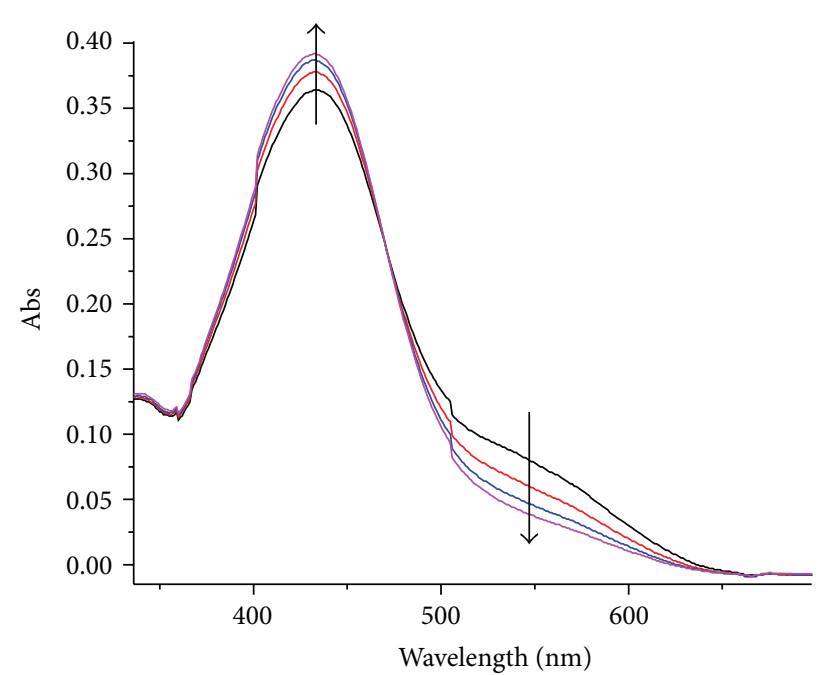

(b)

FIGURE 4: Changes in UV-vis absorption spectra of $2\left(1 \times 10^{-5} \mathrm{M}\right)$ upon the addition of (a) 0.3 equiv. $\mathrm{Hg}^{2+}$ and (b) 4 equiv. $\mathrm{Zn}^{2+}$, all in DMSO at $25^{\circ} \mathrm{C}$.

could not disappear completely even when excess amount of $\mathrm{Zn}^{\mathrm{II}}$ was added.

Consequently, more titrations were carried out in order to understand the similarities and differences of $\mathbf{2}$ towards $\mathrm{Hg}^{\mathrm{II}}$ and $\mathrm{Zn}^{\mathrm{II}}$. Firstly, the addition of $\mathrm{Hg}^{\mathrm{II}}$ to 2 resulted in the complete disappearance of the band at $534 \mathrm{~nm}$ after only 0.3 equiv., while enhancement was experienced at $440 \mathrm{~nm}$. To this, $\mathrm{AcO}^{-}$molar equiv. was added, which saw the reappearance of the enhanced band at $534 \mathrm{~nm}$ simultaneously with the gradual disappearance of the band at $440 \mathrm{~nm}$ (Figure 8(a)). Conversely, reversing the mixing order by adding $\mathrm{AcO}^{-}$ to 2 first, followed by $\mathrm{Hg}^{\mathrm{II}}$, resulted in all changes to be restored back to the initial free sensor (2); however, further addition of $\mathrm{Hg}^{\mathrm{II}}$ caused the disappearance of the $534 \mathrm{~nm}$ band
(Figure 8(b)). Deducing from this, it can safely be concluded that the association constant of $\mathrm{Hg}^{\mathrm{II}}$ is higher with anions $\left(\mathrm{AcO}^{-}\right)$than with 2. Secondly, comparative titration studies were carried out using $\mathrm{Zn}^{\mathrm{II}}$ instead of $\mathrm{Hg}^{\mathrm{II}}$. It was confirmed that $\mathrm{Zn}^{\mathrm{II}}$ can only reverse and restore the original status of 2; however, further addition after the restoration did not result in any significant spectral changes, even when excess amount was added (Figures $8(\mathrm{c})$ and $8(\mathrm{~d})$ ). The overall summation drawn from this system was that 2 showed strong interactions with $\mathrm{Hg}^{\mathrm{II}}$ compared to $\mathrm{Zn}^{\mathrm{II}}$ irrespective of the presence of anions. On the other hand, $\mathrm{Zn}^{\mathrm{II}}$ can only slightly interact with 2 in the absence of the anions (Figure 4(b)), while weak or no interaction was observed in the presence of anions (Figure $8(\mathrm{c})$ ). Therefore, $\mathrm{Zn}^{\mathrm{II}}$ in this case is only suited for 


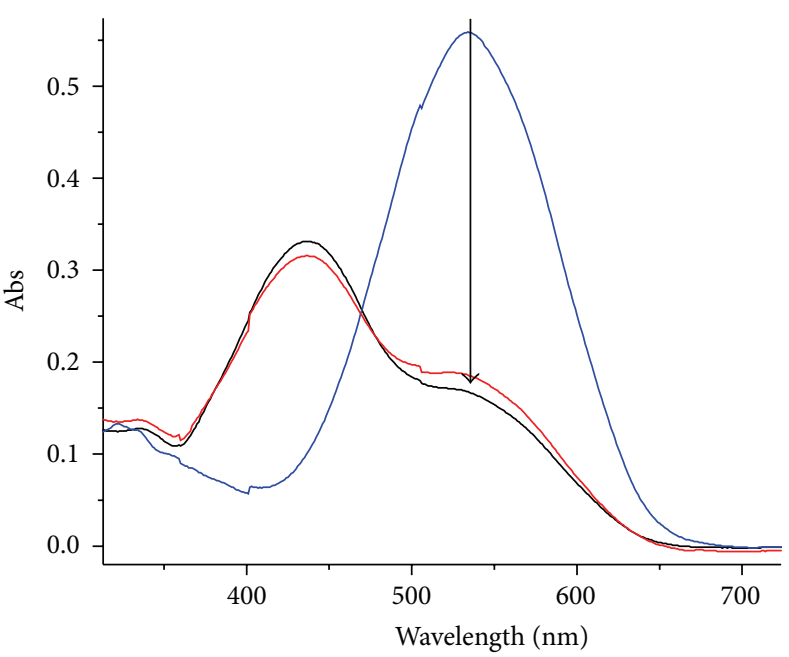

$\begin{array}{ll}- & 2 \\ - & 2 \\ -\quad & 2+2 \mathrm{~F}^{-} \\ - & 2 \mathrm{~F}^{-}+1.2 \mathrm{Zn}^{\mathrm{II}}\end{array}$

(a)

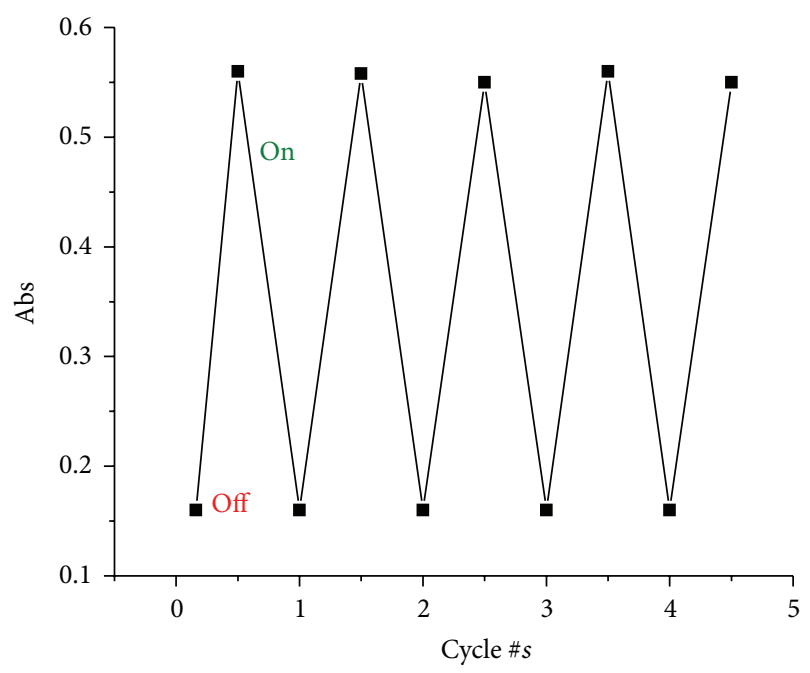

(b)

FIGURE 5: Reversible cycles and reproducible colorimetric switch of $2\left(1 \times 10^{-5} \mathrm{M}\right.$, in DMSO) modulated by the addition of $\mathrm{F}^{-}$and $\mathrm{Zn}^{2+}$ $(\simeq 2: 1)$, respectively. (a) Spectral display of the first cycle. (b) Repeating cycles.

\begin{tabular}{cccc}
\hline $\mathrm{In}_{1}\left(\mathrm{~F}^{-}\right)$ & $\mathrm{In}_{2}\left(\mathrm{Zn}^{\mathrm{II}}\right)$ & $\mathrm{IMP}_{440 \mathrm{~nm}}$ & $\mathrm{INH}_{534 \mathrm{~nm}}$ \\
\hline 0 & 0 & 1 & 0 \\
1 & 0 & 0 & 1 \\
0 & 1 & 1 & 0 \\
1 & 1 & 1 & 0 \\
\hline
\end{tabular}

(a)

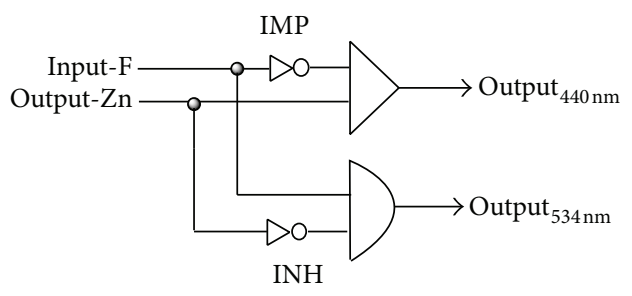

(b)

FIGURE 6: Schematic representation of (a) truth table and (b) a combinatorial IMP/INH logic circuit.

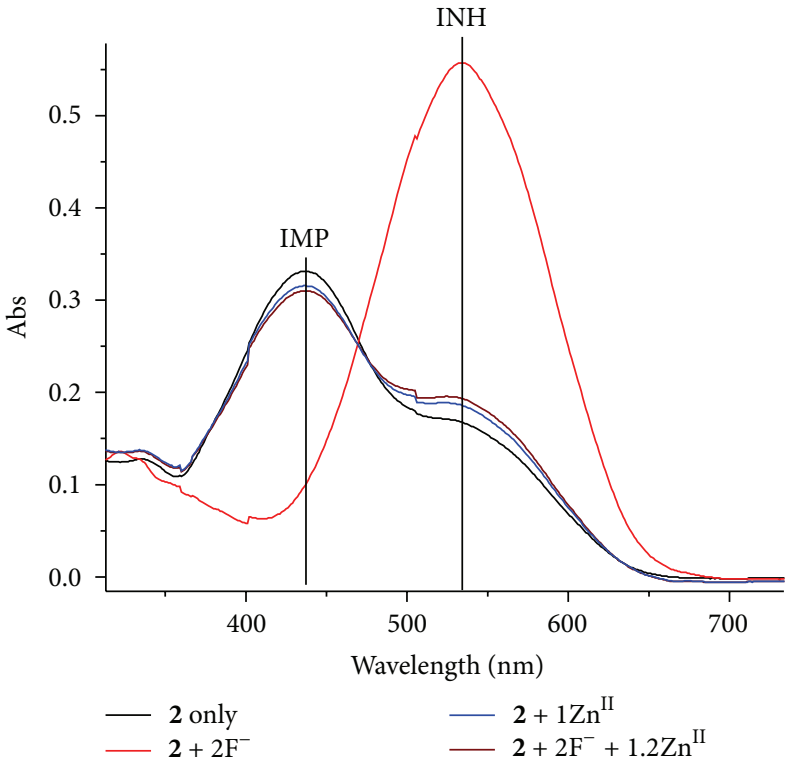

(a)

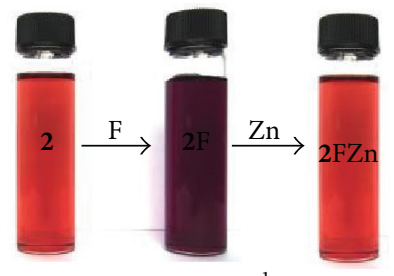

$100 \mu \mathrm{mol} \cdot \mathrm{L}^{-1}$

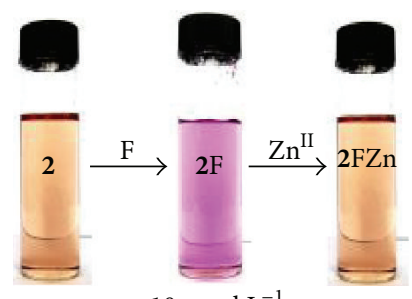

$10 \mu \mathrm{mol} \cdot \mathrm{L}^{-1}$

(b)

FIGURE 7: (a) UV-vis spectra of $2\left(1 \times 10^{-5} \mathrm{M}\right)$ in DMSO with different combinations of $\mathrm{F}^{-}$and $\mathrm{Zn}^{\mathrm{II}}$ and molecular logic functions "IMP" $(440 \mathrm{~nm})$ and "INH" (534 nm). (b) Reversible colorimetric activities of 2 with $\mathrm{F}^{-}$and $\mathrm{Zn}^{\mathrm{II}}$. 


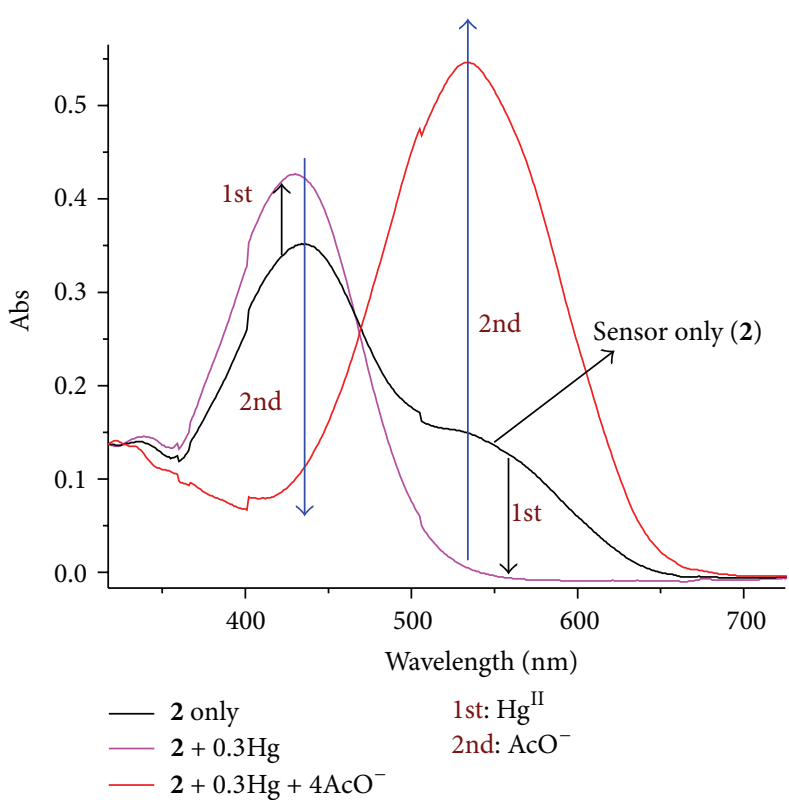

(a)

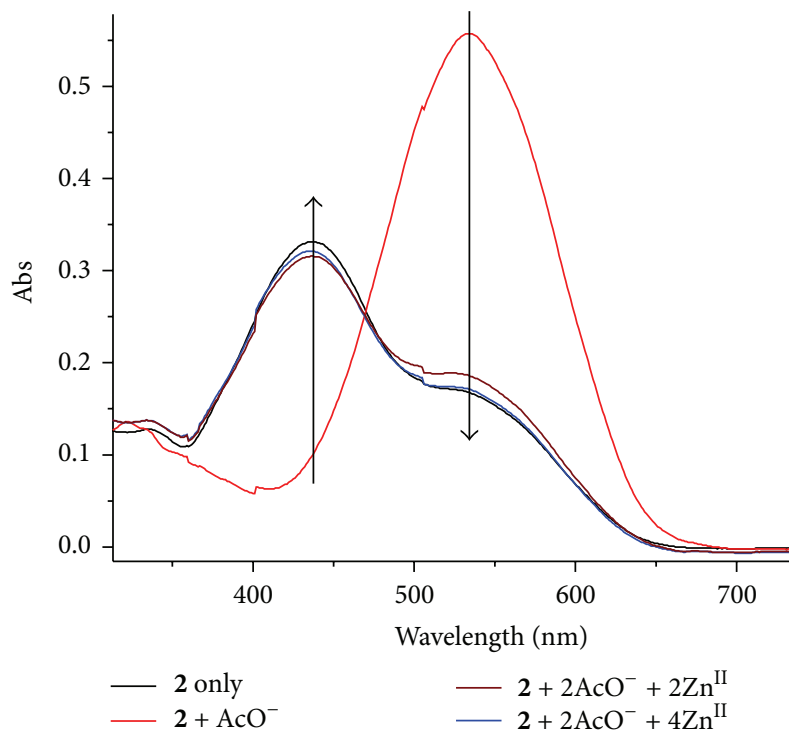

(c)

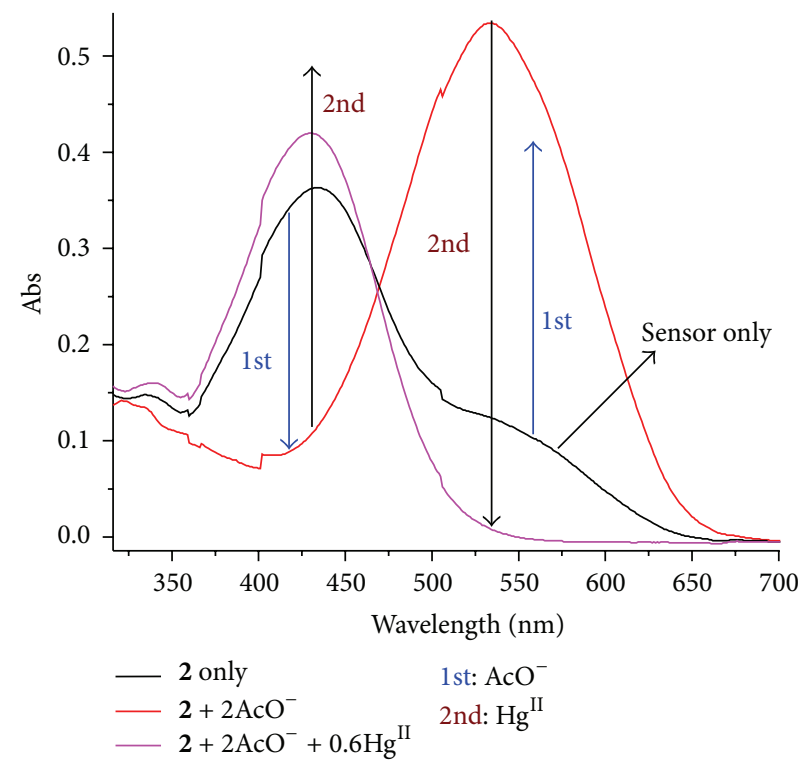

(b)

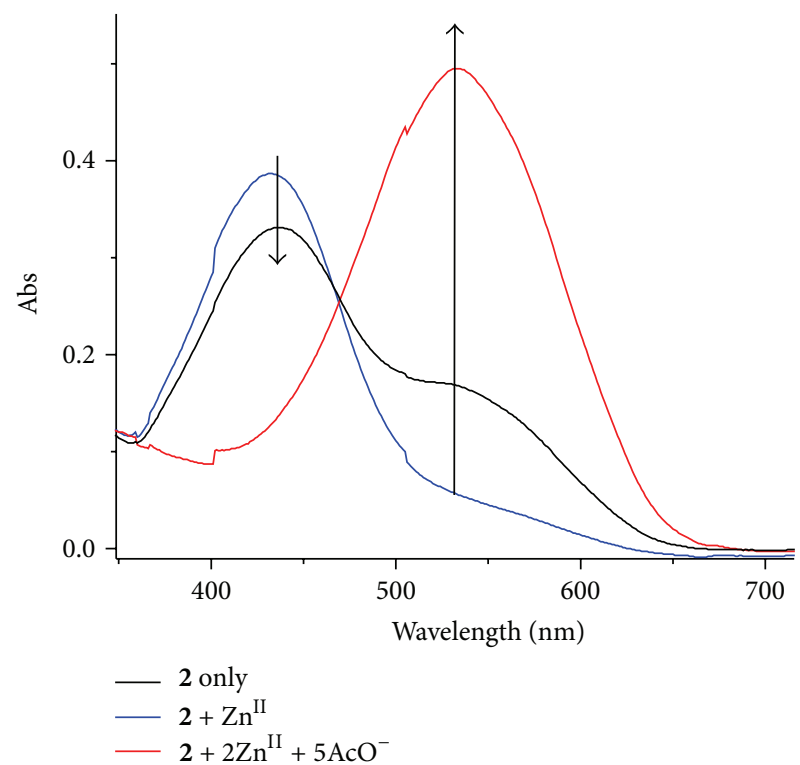

(d)

FIGURE 8: UV-vis titrations for $2\left(1 \times 10^{-5} \mathrm{M}\right)$ in DMSO, displaying reversible effects upon the additions of $(\mathrm{a}) \mathrm{Hg}^{\mathrm{II}}$ then $\mathrm{AcO}^{-}$, (b) $\mathrm{AcO}^{-}$then $\mathrm{Hg}^{2+}$, (c) $\mathrm{AcO}^{-}$then $\mathrm{Zn}^{\mathrm{II}}$, and (d) $\mathrm{Zn}^{\mathrm{II}}$ then $\mathrm{AcO}^{-}$.

logic operation functions as an input for the reverse and restoration of $\mathbf{2}$. Therefore, this means $\mathbf{2}$ not only serves as an anion $\left(\mathrm{AcO}^{-}, \mathrm{F}^{-}\right.$, etc.) sensor, with logic operation functions, but also is simultaneously a cation $\left(\mathrm{Hg}^{\mathrm{II}}\right)$ sensor, suspected to interact via coordination with nitrogen and sulphur atoms in the structure.

The colorimetric activities are heavily dependent on the concentration of sensor. For instance, at $100 \mu \mathrm{mol} \cdot \mathrm{L}^{-1}$, the addition of $\mathrm{F}^{-}$to 2 resulted in the change of color from orange to deep violet, while similar addition of $\mathrm{F}^{-}$to 2 at $10 \mu \mathrm{mol} \cdot \mathrm{L}^{-1}$ saw the change in color from light orange to pink
(Figure 9(b)). Furthermore, the molar addition of $\mathrm{Hg}^{2+}$ to 2 at $100 \mu \mathrm{mol} \cdot \mathrm{L}^{-1}$ resulted in an intense yellow color (from orange), while light yellow color was observed at $10 \mu \mathrm{mol} \cdot \mathrm{L}^{-1}$ (Figure 9(a)).

3.5. DFT Studies of $\mathbf{2}$ with Anions. Applying theoretical approaches based on evidences from the spectroscopic data, molecular modeling calculations (DFT) at $\mathrm{B} 3 \mathrm{LYP} / 6-31 \mathrm{G}^{*}$ level in DMSO were performed to simulate or predict the possible geometrical conformation of $\mathbf{2}$ and the complexed mode 2-F. Accordingly, upon optimizing the structures evident 


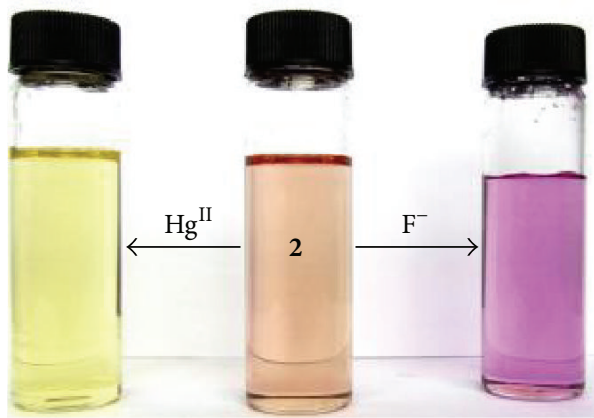

$10 \mu \mathrm{mol} \cdot \mathrm{L}^{-1}$

(a)

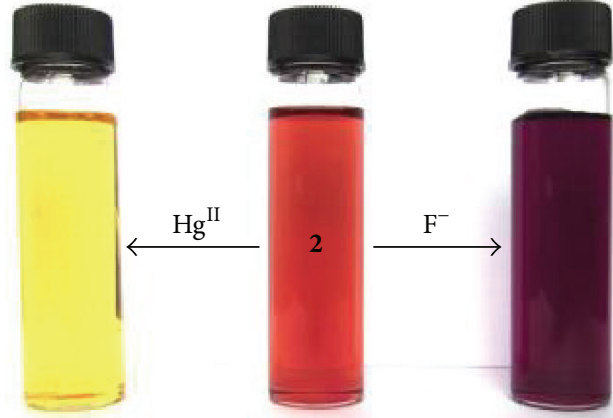

$100 \mu \mathrm{mol} \cdot \mathrm{L}^{-1}$

(b)

Figure 9: Colorimetric activities observed upon the additions of $\mathrm{Hg}^{2+}$ or $\mathrm{F}^{-}$to 2 at different concentrations: (a) $10 \mu \mathrm{mol} \cdot \mathrm{L}^{-1}$ and (b) $100 \mu \mathrm{mol} \cdot \mathrm{L}^{-1}$.

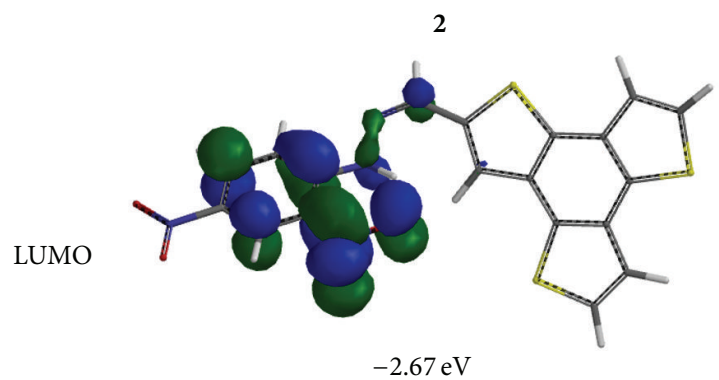

$-2.67 \mathrm{eV}$

HOMO

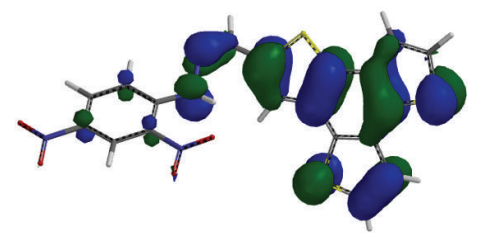

$-5.76 \mathrm{eV}$

Optimized structure (energy gap)

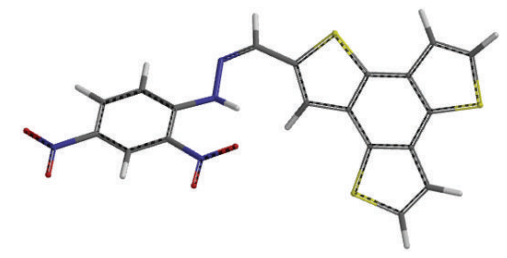

$(3.09 \mathrm{eV})$

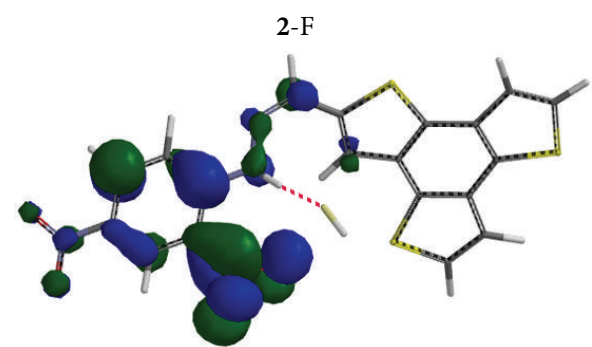

$-2.55 \mathrm{eV}$
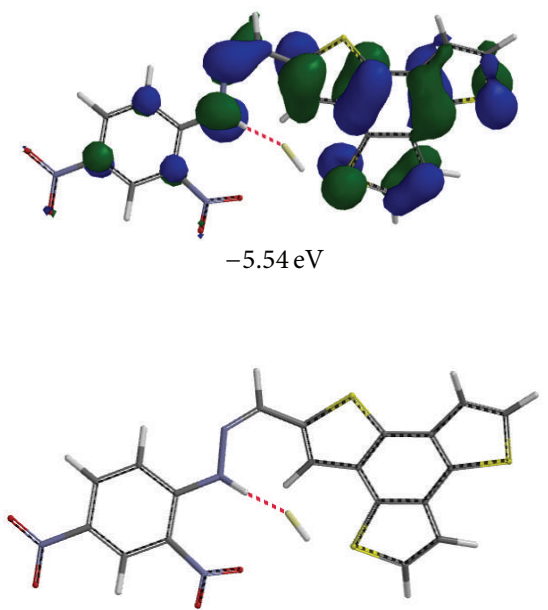

$(2.99 \mathrm{eV})$

FIgURE 10: HOMO and LUMO diagrams of $\mathbf{2}$ in the presence and absence of $\mathrm{F}^{-}$in DMSO.

correlations in structural differences between $\mathbf{2}$ and the $2-\mathrm{F}$ adduct were observed as shown in Figure 10. For instance, the presence of $\mathrm{F}^{-}$saw the whole structure slightly elongate from 14.247 to $14.449 \AA$ (N1 to S14, two furthest points) which resulted in $4.68^{\circ}$ structural distortion as revealed by the peripheral structure angle $\left(\mathrm{N}_{1} \mathrm{C}_{15} \mathrm{~S}_{14}\right)$ increase, from 131.02 to $135.70^{\circ}$ (Figure 11). The initially planar $\mathrm{NO}_{2}$ group to the benzene ring experienced distortion upon the introduction of $\mathrm{F}^{-}$. Overwhelmingly, there is more evidence suggesting that the interaction between $\mathbf{2}$ and $\mathrm{F}^{-}$is within the conclave region of $-\mathrm{NH}$; for example, the distance between closest $\mathrm{NO}_{2}$ (N14) and the $-\mathrm{NH}(\mathrm{N} 8)$ increased significantly from 2.533 to $2.721 \AA$, due to hydrogen bonding interaction between $\mathrm{NH}$ and $\mathrm{F}^{-}$resulting in $\mathrm{NH}-\mathrm{F}$ as indicated (Figure 11). In addition, Mulliken's atomic charges at the nitrogen atom of$\mathrm{NH}$ changed from -0.540 to -0.568 with the formation of the complex 2-F. The increase of the negative charge environment confirms the intercharge transfer (ICT) between 2 and $\mathrm{F}^{-}$, 


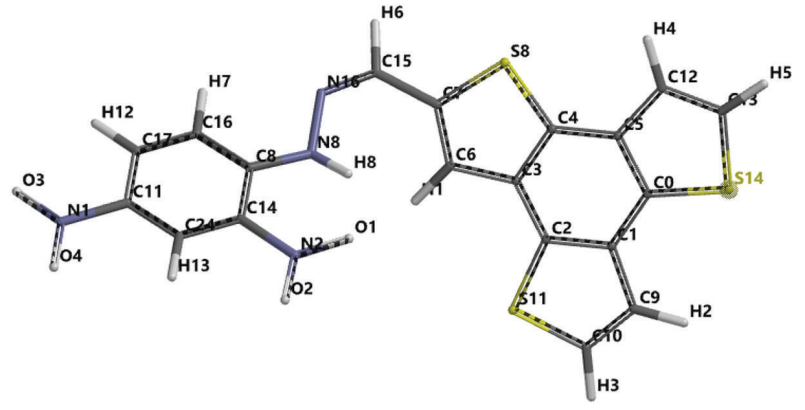

FIGURE 11: Optimized structure showing the positions of atoms.

which lowers down the energy levels of the frontier orbitals through the stabilization of $\pi^{*}$ excited state of 2 by charge delocalization. The HOMO-LUMO gaps of the complexes of 2 have decreased (Figure 10) and this signifies the decrease in the molecular energy and thus stability. Lowering of the HOMO-LUMO gap is responsible for absorption to be redshifted to longer wavelength and thus the pink coloration is observed.

\section{Conclusion}

In summary, we have succeeded in synthesizing a dual colorimetric sensor for both anions and cation based on a simple one-step reaction, with high selectivity and sensitivity responses. The spectroscopic and visual observations made were all correlating with theoretical studies undertaken. This module has very excellent properties which can be developed and translated further into industrial based applications for sensing or even more for molecular logic functions, such as keypad locks.

\section{Competing Interests}

The authors declare that they have no competing interests.

\section{Acknowledgments}

This work was supported by the National Natural Science Foundation of China (no. 21101121), the Natural Science Fund (no. 2010CDB01301) of Hubei Province, and Dalian University of Technology State Key Laboratory of Fine Chemicals Fund (no. KF0912), as well as the Research and Publication Unit (no. URPC/2014/153) of the University of Namibia, Namibia.

\section{References}

[1] J. H. Borroughes, D. D. C. Bradley, A. R. Brown et al., "Lightemitting diodes based on conjugated polymers," Nature, vol. 347, pp. 539-541, 1990.

[2] P. Garcia, J. Penuut, P. Hapiot et al., "Effect of end substitution on electrochemical and optical properties of oligothiophenes," The Journal of Physical Chemistry, vol. 97, pp. 513-516, 1993.
[3] J. M. Tour, "Conjugated macromolecules of precise length and constitution. Organic synthesis for the construction of nanoarchitectures," Chemical Reviews, vol. 96, no. 1, pp. 537-553, 1996.

[4] G. Horowitz, "Organic field-effect transistors," Advanced Materials, vol. 10, no. 5, pp. 365-377, 1998.

[5] F. Cherionx and L. Guyard, "Synthesis and electrochemical properties of novel 1,3,5-tris(oligothienyl)benzenes: a new generation of 3D reticulating agents," Advanced Funtional Materials, vol. 11, no. 4, pp. 305-309, 2001.

[6] A. Facchetti, M.-H. Yoon, C. L. Stern, G. R. Hutchison, M. A. Ratner, and T. J. Marks, "Building blocks for N-type molecular and polymeric electronics. Perfluoroalkyl- versus alkylfunctionalized oligothiophenes (nTs; $n=2-6$ ). Systematic synthesis, spectroscopy, electrochemistry, and solid-state organization," Journal of the American Chemical Society, vol. 126, no. 41, pp. 13480-13501, 2004.

[7] M. X. Chen, E. Perzon, N. Robisson et al., "Low band gap donor-acceptor-donor polymers for infra-red electroluminescence and transistors," Synthetic Metals, vol. 146, no. 3, pp. 233236, 2004.

[8] K. Mullen and U. Scherf, Organic light Emitting Devices, Synthesis, Properties and Applications, Wiley-VCH, New York, NY, USA, 2006.

[9] C. Brabec, V. Dyakonov, and U. Scherf, Eds., Organic Photovoltaic Materials, Device Physics and Manufacturing Technologies, Springer, Heidelberg, Germany, 2008.

[10] P. M. Beaujuge, S. Ellinger, and J. R. Reynolds, "The donoracceptor approach allows ablack-to-transmissive switching polymeric electrochrome," Nature Materials, vol. 7, no. 10, pp. 795-799, 2008.

[11] F. Cherionx and L. Guyard, "Synthesis and electrochemical properties of novel 1,3,5-tris(oligothienyl)benzenes: a new generation of 3D reticulating agents," Advanced Funtional Materials, vol. 11, no. 4, pp. 305-309, 2001.

[12] Y. Nicolas, P. Blanchard, E. Levillain, M. Allain, N. Mercier, and J. Roncali, "Planarized star-shaped oligothiophenes with enhanced $\pi$-electron delocalization," Organic Letters, vol. 6, no. 2, pp. 273-276, 2004.

[13] I. F. Perepichka and D. I. Perepichka, Handbook of ThiopheneBased Materials: Applications in Organic Electronics and Photonics, John Wiley \& Sons, London, UK, 2009.

[14] P. M. Beaujuge, W. Pisula, N. T. Hoi, S. Ellinger, K. Müllen, and J. R. Reynolds, "Tailoring structure-property relationships in dithienosilole- benzothiadiazole donor-acceptor copolymers," Journal of the American Chemical Society, vol. 131, no. 22, pp. 7514-7515, 2009.

[15] T. Taerum, O. Lukoyanova, R. G. Wylie, and D. F. Perepichka, "Synthesis, polymerization, and unusual properties of new starshaped thiophene oligomers," Organic Letters, vol. 11, no. 15, pp. 3230-3233, 2009.

[16] P. M. Beaujuge, J. Subbiah, K. R. Choudhury et al., "Green dioxythiophene-benzothiadiazole donor-acceptor copolymers for photovoltaic device applications," Chemistry of Materials, vol. 22, no. 6, pp. 2093-2106, 2010.

[17] X. Guo, S. Wang, V. Enkelmann, M. Baumgarten, and K. Müllen, "Making benzotrithiophene a stronger electron donor," Organic Letters, vol. 13, no. 22, pp. 6062-6065, 2011.

[18] T. Kashiki, M. Kohara, I. Osaka, E. Miyazaki, and K. Takimiya, "Synthesis and characterization of benzo[1, 2- $b: 3,4-b$ ':5, 6$b^{\prime \prime}$ trithiophene (BTT) oligomers," Journal of Organic Chemistry, vol. 76, no. 10, pp. 4061-4070, 2011. 
[19] K. M. N. De Silva, E. Hwang, W. K. Serem, F. R. Fronczek, J. C. Garno, and E. E. Nesterov, "Long-chain 3,4-ethylenedioxythiophene/thiophene oligomers and semiconducting thin films prepared by their electropolymerization," ACS Applied Materials and Interfaces, vol. 4, no. 10, pp. 5430-5441, 2012.

[20] X. Guo, S. R. Puniredd, M. Baumgarten, W. Pisula, and K. Müllen, "Benzotrithiophene-based donor-acceptor copolymers with distinct supramolecular organizations," Journal of the American Chemical Society, vol. 134, no. 20, pp. 8404-8407, 2012.

[21] T.-A. Liu, C. Prabhakar, J.-Y. Yu, C.-H. Chen, H.-H. Huang, and J.-S. Yang, "Star-shaped oligothiophenes containing an isotruxene core: synthesis, electronic properties, electropolymerization, and film morphology," Macromolecules, vol. 45, no. 11, pp. 4529-4539, 2012.

[22] A. L. Dyer, M. R. Craig, J. E. Babiarz, K. Kiyak, and J. R. Reynolds, "Orange and red to transmissive electrochromic polymers based on electron-rich dioxythiophenes," Macromolecules, vol. 43, no. 10, pp. 4460-4467, 2010.

[23] P. Sista, B. Xue, M. Wilson et al., "Influence of the alkyl substituents spacing on the solar cell performance of benzodithiophene semiconducting polymers," Macromolecules, vol. 45, no. 2, pp. 772-780, 2012.

[24] D. Tyler McQuade, A. E. Pullen, and T. M. Swager, "Conjugated polymer-based chemical sensors," Chemical Reviews, vol. 100, no. 7, pp. 2537-2574, 2000.

[25] S. W. Thomas III, K. Venkatesan, P. Müller, and T. M. Swager, "Dark-field oxidative addition-based chemosensing: new biscyclometalated $\mathrm{Pt}$ (II) complexes and phosphorescent detection of cyanogen halides," Journal of the American Chemical Society, vol. 128, no. 51, pp. 16641-16648, 2006.

[26] F. Wang, H. Gu, and T. M. Swager, "Carbon nanotube/polythiophene chemiresistive sensors for chemical warfare agents," Journal of the American Chemical Society, vol. 130, no. 16, pp. 5392-5393, 2008.

[27] D.-S. Kim and H. A. Kyo, "Fluorescence 'turn-on' sensing of carboxylate anions with oligothiophene-based o-(carboxamido)trifluoroacetophenones," Journal of Organic Chemistry, vol. 73, no. 17, pp. 6831-6834, 2008.

[28] T. T. Steckler, X. Zhang, J. Hwang et al., "A spray-processable, low bandgap, and ambipolar donor-acceptor conjugatedpolymer," Journal of the American Chemical Society, vol. 131, no. 8, pp. 2824-2826, 2009.

[29] K. K. Upadhyay, A. Kumar, R. K. Mishra, T. M. Fyles, S. Upadhyay, and K. Thapliyal, "Reversible colorimetric switching of thiophene hydrazone based on complementary IMP/INH logic functions," New Journal of Chemistry, vol. 34, no. 9, pp. 1862-1866, 2010.

[30] S. L. A. Kumar, R. Tamilarasan, M. S. Kumar, and A. Sreekanth, "Bisthiocarbohydrazones as colorimetric and 'turn on' fluorescent chemosensors for selective recognition of fluoride," Industrial and Engineering Chemistry Research, vol. 50, no. 22, pp. 12379-12383, 2011.

[31] L. Mosca, P. Koutnik, V. M. Lynch, G. V. Zyryanov, N. A. Esipenko, and P. Anzenbacher Jr., "Host-guest complexes of pentiptycene receptors display edge-to-face interaction," Crystal Growth and Design, vol. 12, no. 12, pp. 6104-6109, 2012.

[32] Y.-H. Qiao, H. Lin, and H.-K. Lin, "A novel colorimetric sensor for anions recognition based on disubstituted phenylhydrazone," Journal of Inclusion Phenomena and Macrocyclic Chemistry, vol. 59, no. 3-4, pp. 211-215, 2007.
[33] J. Li, H. Lin, P. Jiang, and H. Lin, "An optical and electrochemical anion sensor of $\mathrm{F}^{-}$investigated by UV-vis, $1 \mathrm{H}$ NMR and cyclic voltammetry," Journal of Inclusion Phenomena and Macrocyclic Chemistry, vol. 62, no. 3-4, pp. 209-213, 2008.

[34] Y. Wang, H. Lin, J. Shao, Z.-S. Cai, and H.-K. Lin, "A phenylhydrazone-based indole receptor for sensing acetate," Talanta, vol. 74, no. 5, pp. 1122-1125, 2008.

[35] J. Shao, Y. Qiao, H. Lin, and H.-K. Lin, "A $C_{3}$-symmetric colorimetric anion sensor bearing hydrazone groups as binding sites," Spectrochimica Acta Part A: Molecular and Biomolecular Spectroscopy, vol. 71, no. 5, pp. 1736-1740, 2009.

[36] J. Li, Y. Wang, H. Len, and H. Lin, "A novel, simple, colorimetric receptor based on $2^{\prime}, 4^{\prime}$ - dinitrophenylhydrazone for acetate ion in organic medium," Journal of Inclusion Phenomena and Macrocyclic Chemistry, vol. 63, no. 3-4, pp. 281-285, 2009.

[37] X.-F. Shang and X.-F. Xu, "The anion recognition properties of hydrazone derivatives containing anthracene," BioSystems, vol. 96, no. 2, pp. 165-171, 2009.

[38] P. Singh, J. Kaur, and W. Holzer, "Acridone based $\mathrm{Cu}^{2+}-\mathrm{F}^{-} / \mathrm{F}^{-}-$ $\mathrm{Cu}^{2+}$ responsive ON/OFF key pad," Sensors and Actuators B: Chemical, vol. 150, no. 1, pp. 50-56, 2010.

[39] C. N. Carroll, B. A. Coombs, S. P. McClintock et al., "Aniondependent fluorescence in bis(anilinoethynyl)pyridine derivatives: switchable ON-OFF and OFF-ON responses," Chemical Communications, vol. 47, no. 19, pp. 5539-5541, 2011.

[40] E. Manandhar and K. J. Wallace, "Host-guest chemistry of pyrene-based molecular receptors," Inorganica Chimica Acta, vol. 381, no. 1, pp. 15-43, 2012.

[41] W. Lu, M. Zhang, K. Liu, B. Fan, Z. Xia, and L. Jiang, "A fluorideselective colorimetric and fluorescent chemosensor and its use for the design of molecular-scale logic devices," Sensors and Actuators B: Chemical, vol. 160, no. 1, pp. 1005-1010, 2011.

[42] Q. Li, Y. Yue, Y. Guo, and S. Shao, "Fluoride anions triggered 'OFF-ON' fluorescent sensor for hydrogen sulfate anions based on a BODIPY scaffold that works as a molecular keypad lock," Sensors and Actuators B: Chemical, vol. 173, pp. 797-801, 2012.

[43] W. Lu, D. Chen, H. Jiang, L. Jiang, and Z. Shen, "Polymer-based fluoride-selective chemosensor: synthesis, sensing property, and its use for the design of molecular-scale logic devices," Journal of Polymer Science, Part A: Polymer Chemistry, vol. 50, no. 3, pp. 590-598, 2012.

[44] V. Uahengo, B. Xiong, N. Zhou, P. Cai, K. Hu, and G. Cheng, "Synthesis of a phenylhydrazone-based colorimetric anion sensor with complementary IMP/INH logic functions," Chinese Journal of Chemistry, vol. 30, no. 8, pp. 1702-1708, 2012.

[45] M. Ikeda, A. Matsu-Ura, S. Kuwahara, S. S. Lee, and Y. Habata, " $\mathrm{Hg}^{2+}$-sensing system based on structures of complexes," Organic Letters, vol. 14, no. 6, pp. 1564-1567, 2012.

[46] J. Hu, T. Wu, G. Zhang, and S. Liu, "Highly selective fluorescence sensing of mercury ions over a broad concentration range based on mixed polymeric micelles," Macromolecules, vol. 45, no. 9, pp. 3939-3947, 2012.

[47] L.-N. Neupane, P. Thirupathi, S. Jang, M. J. Jang, J. H. Kim, and K.-H. Lee, "Highly selectively monitoring heavy and transition metal ions by a fluorescent sensor based on dipeptide," Talanta, vol. 85, no. 3, pp. 1566-1574, 2011.

[48] T. Li, Z. Yang, Y. Li, Z. Liu, G. Qi, and B. Wang, "A novel fluorescein derivative as a colorimetric chemosensor for detecting copper(II) ion," Dyes and Pigments, vol. 88, no. 1, pp. 103-108, 2011. 
[49] L. Tang, F. Li, M. Liu, and R. Nandhakumar, "Single sensor for two metal ions: colorimetric recognition of $\mathrm{Cu}^{2+}$ and fluorescent recognition of $\mathrm{Hg}^{2+}$," Spectrochimica Acta Part A: Molecular and Biomolecular Spectroscopy, vol. 78, no. 3, pp. 1168-1172, 2011.

[50] H. Hart and M. Sasaoka, "Exocyclic benzenes. Synthesis and properties of benzo[1,2-c:3,4-c':5,6-c" $c^{\prime \prime}$ trithiophene, a tristhiahexaradialene," Journal of the American Chemical Society, vol. 100, no. 13, pp. 4326-4327, 1978. 

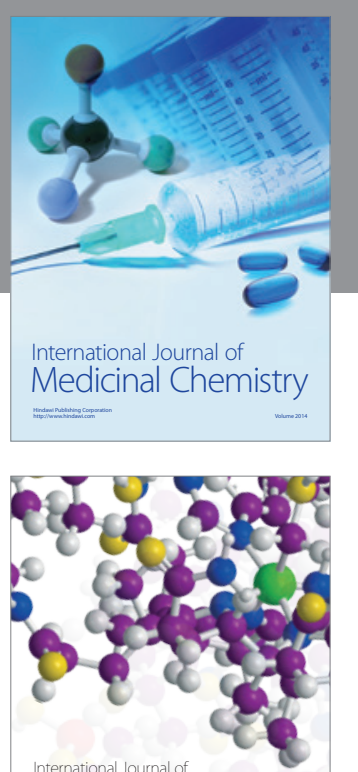

Carbohydrate Chemistry

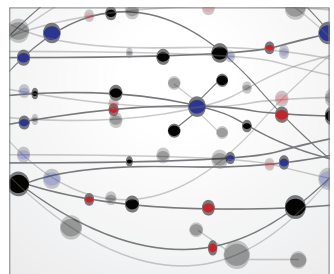

The Scientific World Journal
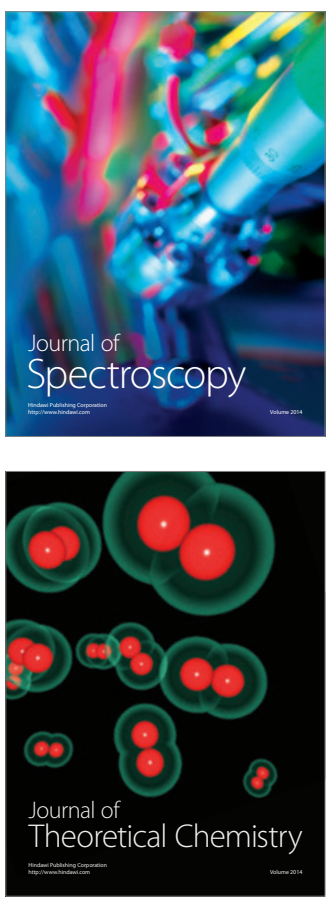
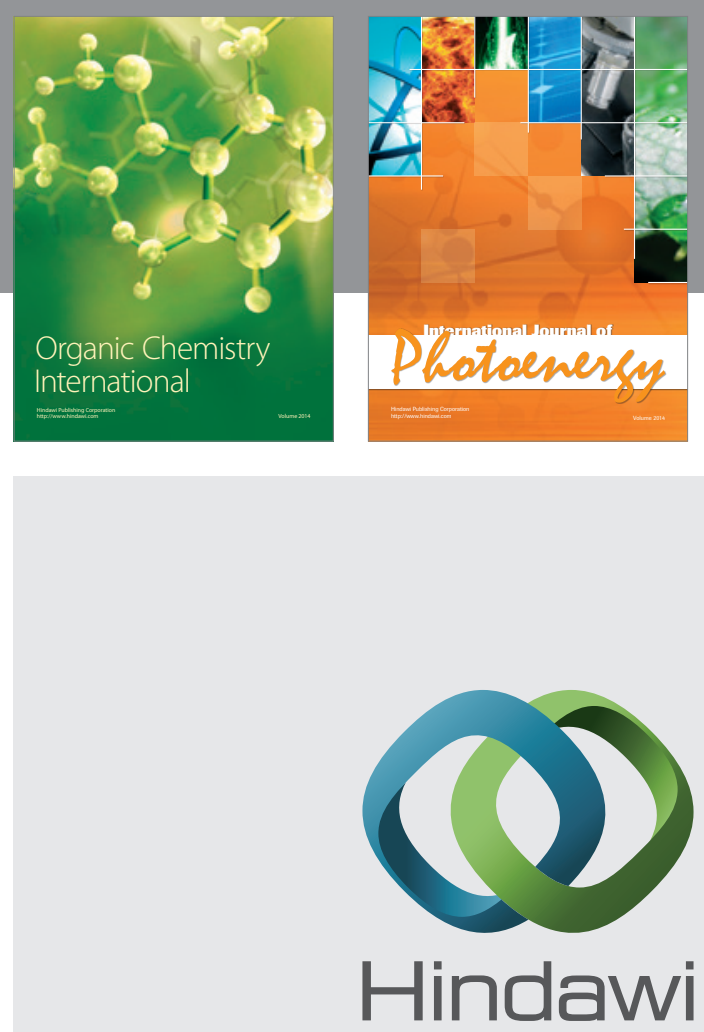

Submit your manuscripts at

http://www.hindawi.com

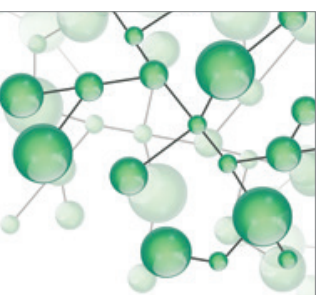

International Journal of

Inorganic Chemistry

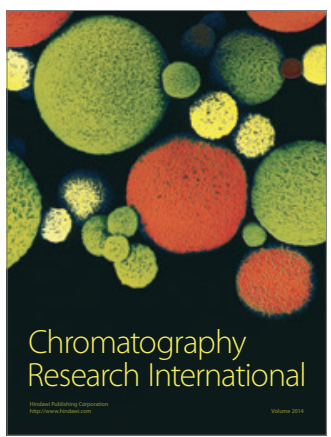

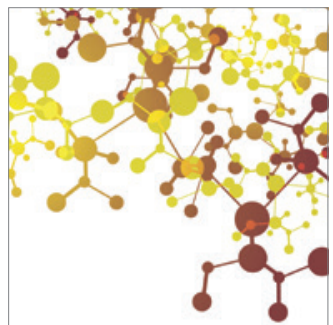

Applied Chemistry
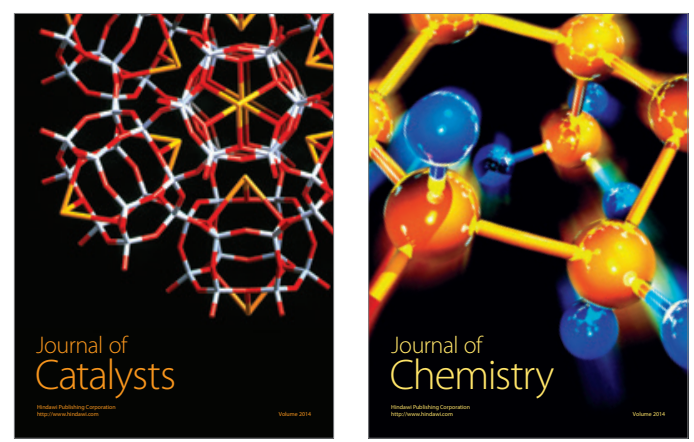
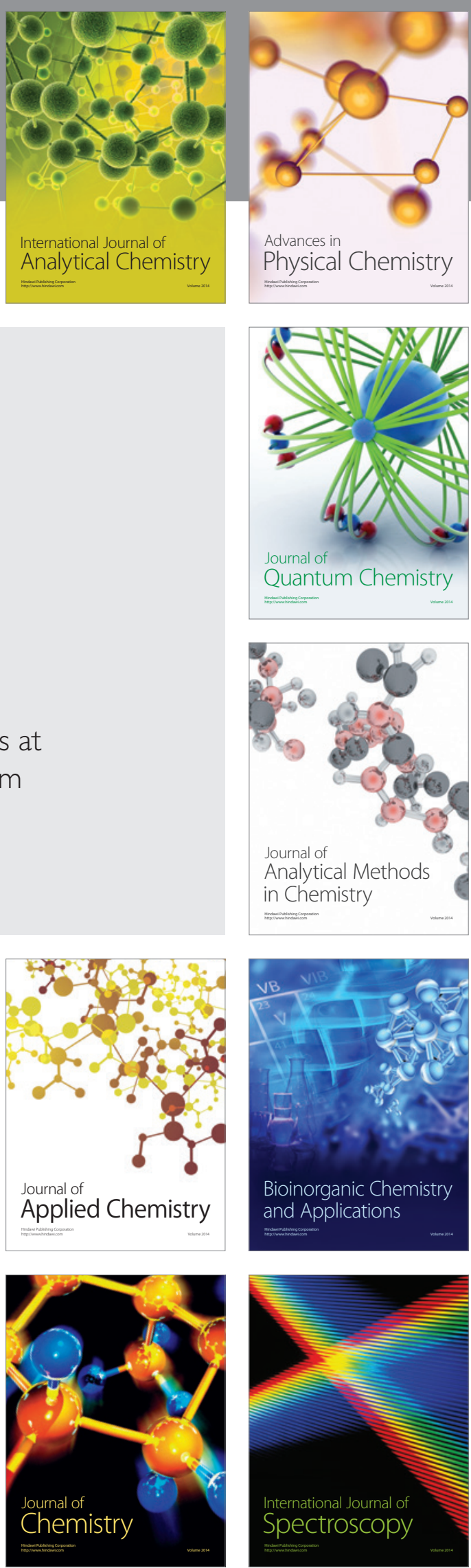